\title{
Waste prevention for sustainable resource and waste management
}

Sakai, Shin-Ichi; Yano, Junya; Hirai, Yasuhiro; Asari, Misuzu; Yanagawa, Ritsuki; Matsuda, Takeshi; Yoshida, Hideto; Yamada, Tetsuji; Kajiwara, Natsuko; Suzuki, Go

Total number of authors:

25

Published in:

Journal of Material Cycles and Waste Management

Link to article, DOI:

$10.1007 / \mathrm{s} 10163-017-0586-4$

Publication date:

2017

Document Version

Publisher's PDF, also known as Version of record

Link back to DTU Orbit

Citation (APA):

Sakai, S-I., Yano, J., Hirai, Y., Asari, M., Yanagawa, R., Matsuda, T., Yoshida, H., Yamada, T., Kajiwara, N., Suzuki, G., Kunisue, T., Takahashi, S., Tomoda, K., Wuttke, J., Mählitz, P., Rotter, V. S., Grosso, M., Astrup, T. F., Cleary, J., ... Moore, S. (2017). Waste prevention for sustainable resource and waste management. Journal of Material Cycles and Waste Management, 19(4), 1295-1313. https://doi.org/10.1007/s10163-017-0586-4

\section{General rights}

Copyright and moral rights for the publications made accessible in the public portal are retained by the authors and/or other copyright owners and it is a condition of accessing publications that users recognise and abide by the legal requirements associated with these rights.

- Users may download and print one copy of any publication from the public portal for the purpose of private study or research.

- You may not further distribute the material or use it for any profit-making activity or commercial gain

- You may freely distribute the URL identifying the publication in the public portal 


\title{
Waste prevention for sustainable resource and waste management
}

\author{
Shin-ichi Sakai ${ }^{1} \cdot$ Junya Yano $^{1} \cdot$ Yasuhiro Hirai $^{1} \cdot$ Misuzu Asari $^{2} \cdot$ Ritsuki Yanagawa $^{1} \cdot$ Takeshi Matsuda $^{1} \cdot$ \\ Hideto Yoshida $^{3}$ - Tetsuji Yamada ${ }^{4}$ Natsuko Kajiwara ${ }^{5} \cdot$ Go Suzuki $^{5}$ ' Tatsuya Kunisue $^{6} \cdot$ Shin Takahashi $^{6}$. \\ Keijiro Tomoda ${ }^{7}$ Joachim Wuttke ${ }^{8} \cdot$ Paul Mählitz $^{9}$ - Vera Susanne Rotter ${ }^{9}$ Mario Grosso $^{10}$.

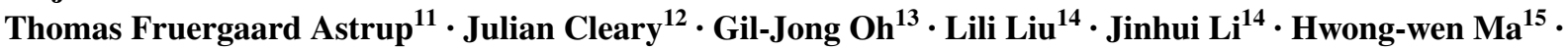 \\ Ngo Kim Chi ${ }^{16} \cdot$ Stephen Moore $^{17}$
}

Received: 22 August 2016 / Accepted: 16 January 2017 / Published online: 21 February 2017

(c) The Author(s) 2017. This article is published with open access at Springerlink.com

\begin{abstract}
Although the 2Rs (reduce and reuse) are considered high-priority approaches, there has not been enough quantitative research on effective $2 \mathrm{R}$ management. The purpose of this paper is to provide information obtained through the International Workshop in Kyoto, Japan, on 11-13 November 2015, which included invited experts and researchers in several countries who were in charge of 3R policies, and an additional review of 245 previous studies. It was found that, regarding policy development, the decoupling between environmental pressures and economy growth was recognized as an essential step towards a sustainable society. $3 \mathrm{R}$ and resource management policies, including waste prevention, will play a crucial role. Approaches using material/substance flow analyses have become sophisticated enough to describe the fate of resources and/or hazardous substances based on human
\end{abstract}

Electronic supplementary material The online version of this article (doi:10.1007/s10163-017-0586-4) contains supplementary material, which is available to authorized users.

Shin-ichi Sakai

sakai@eprc.kyoto-u.ac.jp

1 Kyoto University Environment Preservation Research Center, Kyoto, Japan

2 Kyoto University Graduate School of Global Environmental Studies, Kyoto, Japan

3 Japan Environment Safety Corporation, Tokyo, Japan

4 Environment Policy Bureau, City of Kyoto, Kyoto, Japan

5 National Institute for Environmental Studies, Tsukuba, Japan

6 Ehime University, Matsuyama, Japan

7 TOWA Technology Corporation, Higashihiroshima, Japan

8 Federal Environment Agency, UBA, Dessau-Roßlau, Germany activity and the environment, including the final sink. Lifecycle assessment has also been developed to evaluate waste prevention activities. Regarding target products for waste prevention, food loss is one of the waste fractions with the highest priority because its countermeasures have significant upstream and downstream effects. Persistent organic pollutants and hazardous compounds should also be taken into account in the situation where recycling activities are globally widespread for the promotion of a material-cycling society.

Keywords Waste prevention - Resource efficiency · Chemical control · Material flow analysis (MFA) · Lifecycle assessment (LCA) · Circular economy · Substance flow analysis (SFA) · Life-cycle cost (LCC) · Review 


\section{Introduction}

The $3 \mathrm{R}$ (reduce, reuse, and recycle) initiative is being promoted to establish a sound material-cycle society through the effective use of resources for $3 R$ activities, thereby ensuring both environmental conservation and economic growth $[1,2]$. Furthermore, it is globally recognized that many $3 R$ initiatives contribute to the reduction of greenhouse gas (GHG) emissions. This has led to discussions on how to realize sustainable resource usage, and how to build economic structures that promote highly efficient resource circulation [1-3]. Also, because there are serious unsolved waste management issues, it is essential to develop integrated policies for waste management, including procedures for the proper control of chemicals.

Two of the $3 \mathrm{Rs}(2 \mathrm{R}=$ Reduce and Reuse $)$ are considered high-priority for development [4]. The definitions of waste prevention, reduce, and reuse vary across countries and regions [4]. For instance, the definition of waste prevention in Directive 2008/98/EC in the European Union (EU) includes the reduction of the quantity of toxic substances in materials and products. In contrast, the definition of reduce in Japan refers to reducing the quantity of waste rather than that of toxic substances. However, it is commonly recognized that successful implementation of reduce and reuse principles will lead to the prevention of waste in a society. Quantitative indicators, such as material flow indicators, have been developed and proposed to monitor and evaluate the progress of the $3 R s$, including the $2 \mathrm{R}$ policy [5-9]. However, the indicators that are actually employed in the policy are limited for various reasons, including the lack of statistical data [4]. This is because the amount of quantitative research on effective $2 \mathrm{R}$ management has been limited. Consequently, the effectiveness of various $2 \mathrm{R}$ measures must be determined and analyzed. To promote international comparative research on these topics, we held an International Workshop in Kyoto, Japan, on 11-13 November 2015, which included invited experts and researchers that oversaw $3 \mathrm{R}$ policies in several countries. The workshop facilitated information sharing among participants on various indexes for prevention measures, and the progress status for these approaches in their home countries and regions. The participants were policymakers and researchers from Australia, Canada, China, Denmark, Germany, Italy, Japan, the Republic of Korea, Taiwan, and Vietnam. The purpose of this paper is to provide a summary of the information obtained through the workshop and in an additional review of previous studies that was conducted in June 2016. As listed in Table 1, a total of 245 papers were reviewed. However, due to space limitations, not all can be introduced in this manuscript (see the electronic supplemental materials SI1 for a detailed list). This study consists of three sections: (1) waste prevention policy, concepts and practices in each country, (2) methodologies for decision-making, and (3) target products and/or materials with higher priority. By reviewing current policies for waste prevention in countries around the world, we have observed that (1) decision-making at a policy level is solely dependent on information obtained through material flow analysis (MFA) and life-cycle assessment (LCA), and (2) waste prevention policies target a wide range of materials, from food loss to packaging waste to persistence chemicals.

\section{Status of waste prevention policies in each country}

\section{EU countries}

In the EU, the Thematic Strategy on the Prevention and Recycling of Waste was established in 2005 [10]. Since then, the importance of waste prevention has been recognized. In accordance with the revised Waste Framework Directive (2008/98/EC), Member States must establish national waste prevention programs. The directive draws attention to key environmental impacts to account for products and materials from a life-cycle perspective, and to achieve a decoupling between economic growth and the environmental impacts associated with waste generation [11-14]. By the end of 2014, national or regional waste prevention programs had been developed in 27 of the 31 countries in the EU (28 EU member states and 3 European

Table 1 Number of reviewed papers, methods, and waste types considered

\begin{tabular}{|c|c|c|c|c|c|c|c|c|c|}
\hline \multirow{2}{*}{$\begin{array}{l}\text { Number of reviewed } \\
\text { papers }\end{array}$} & \multicolumn{9}{|l|}{ Methods } \\
\hline & Policy & $\begin{array}{l}\text { Review and } \mathrm{m} \\
\text { ology }\end{array}$ & hod- & $\begin{array}{l}\mathrm{LC} A \\
\text { anal }\end{array}$ & mental & LCC, cost analysis & MFA, SFA & Field survey & Others \\
\hline \multirow[t]{3}{*}{245} & 57 & 71 & & 54 & & 22 & 59 & 39 & 30 \\
\hline & \multicolumn{9}{|c|}{ Considered waste type } \\
\hline & Food waste & Packaging waste & \multicolumn{2}{|c|}{ Battery } & ELV & E-waste & C\&D waste & \multicolumn{2}{|c|}{ Persistent chemicals } \\
\hline 245 & 62 & 41 & 39 & & 35 & 44 & 35 & 43 & \\
\hline
\end{tabular}

Regarding "methods" and "considered waste type", papers were counted more than once 
Free Trade Association countries) [15, 16], and seven programs were first adopted during 2014 [17].

On the other hand, the flagship initiative developed under Europe 2020, which is the growth strategy for the EU until 2020, addresses sustainable growth based on a more competitive, low-carbon economy that also protects the environment. [18-21]. The concept of a "circular economy" was developed in the EU. In contrast to a traditional linear economy, a circular economy represents a development strategy that enables economic growth while optimizing the consumption of natural resources. This requires deep transformations in production chains and consumption patterns, as well as the redesign of industrial systems [22, 23]. It is remarkable that a circular economy is intended to achieve economic growth along with sustainable growth. The European Commission (EC) adopted an ambitious circular economy package in 2015, which consisted of an EU action plan and included revised legislative proposals on waste to stimulate the transition towards a circular economy [24]. Plastics, food waste, critical raw materials, construction and demolition waste, and biomass and bio-based products were identified as priority areas of focus in the action plan. The revised legislative proposals on waste set both quantitative and qualitative targets for the reduction of waste, and established an ambitious and credible long-term path for waste management and recycling.

In Germany, as a result of the progress made in each EU member nation regarding waste management regulations, the Circular Economy Act (CEA) [25] was developed in 2012 and included the concepts of waste prevention and extended producer responsibility. According to the Act, the established waste prevention program [26] emphasized the importance of waste prevention against the background of the waste management hierarchy of the CEA, although it was without legal commitments. The program outlined the potential for administrative bodies to prevent waste for the first time in a systematic and comprehensive way. The program also introduced 34 specific waste prevention measures along with an evaluation of their effectiveness. Some of the recommendations were for local authorities to develop waste prevention concepts and plans, to provide information and raise awareness regarding clean product design, and to strengthen the waste prevention aspects of purchase recommendations.

Since the 1990s, waste treatment in Denmark shifted from a landfill focus to incineration [27]. In 2011, 61, 29, and $6 \%$ of all waste was recycled, incinerated, and landfilled, respectively. In promoting the subsequent shift from incineration to recycling, Denmark established a resource strategy with the goal to increase the portion of household waste recycled from 22 to $50 \%$ by 2022 , to collect $65 \%$ of all waste electrical and electronic equipment (WEEE), including 55\% of all portable batteries sold in the market in
2018, and so on [27]. As for waste prevention in Denmark, efforts are focused on food waste, construction and demolition $(\mathrm{C} \& \mathrm{D})$ waste, textile waste, WEEE, and packaging waste.

In Italy, the National Programme for Waste Prevention includes prevention targets to be achieved by the year 2020 with respect to 2010 [28]. They include a 5\% reduction in the amount of urban and non-hazardous waste generated, and a $10 \%$ reduction in that for hazardous waste. Both percentage targets will be calculated per GDP unit to achieve a decoupling between waste generation and economic indicators.

\section{Asia and Pacific countries}

The Basic Act on Establishing a Sound Material-Cycle Society was established in Japan in 2000 [29]. The Act was intended to limit the consumption of natural resources and to minimize the associated environmental burden by promoting the 3Rs, including "reduce" (waste prevention), as well as environmentally sound waste management practices. In accordance with the Basic Act, the 1st-3rd Fundamental Plans, which were comprehensive waste management plans that included methods to "reduce" waste, were established in 2003, 2008, and 2013, respectively [1, 30-33]. Of the five key areas in the 3rd Fundamental Plan, the plan defined (1) $2 \mathrm{R}$ promotion, and (2) the advanced use of recyclable resources and the promotion of critical metal recovery. Regarding each recycling law, the Law for the Promotion of Recycling and Related Activities for the Treatment of Cyclical Food Resources (enforced in 2001, revised in 2007) [34] set reduction targets (reduction weight per number of sales) for 31 business sectors after August 2015. Furthermore, among local authorities, Kyoto City set a reduction target in the revised action plan 2015 to reduce food loss by half as of 2020, compared with the maximum level registered in 2000 [35].

One of the representative waste management policies in South Korea involves the extended producer responsibility (EPR) system and the volume-based waste fee system. As a consequence of the Waste Deposit Program implemented in 1992, a full-fledged EPR system was introduced in 2003 to impose recycling obligations on producers [36]. The volume-based waste fee system was launched in 1994 in accordance with the polluter pays principle [37-39]. This system is applicable to residential waste from households and businesses, and was recently expanded to cover food waste as part of the comprehensive measures for food waste reduction in 2010. As of June 2014, 142 of 145 local governments were participating in this system [39]. The first fundamental plan for resource circulation was established in 2011, and followed the Waste Control Act (amended in 2015) and the Act on Promotion of Saving and Recycling 
of Resources (amended in 2016), which were both based on the principle of resource circulation, [39]. To promote the transition to a resource circulation society, additional measures were launched in 2013 that included: free pickup services for large-scale waste home appliances, securing collection services, transportation and classification of recycling resources, expansion of "waste to energy" facilities, and the creation of a recycling marketplace. The Framework Act on Resource Recirculation was legislated in May, 2016 (to be enforced from January 2018). Like the EU member states and Japan, Korea has also implemented a food waste prevention policy, which envisions an ecofriendly food culture, and an energy-saving low-carbon society with the target of a $20 \%$ reduction in the amount of food waste generated by 2012, compared to the 2008 level [40]. The strategy included setting up a system of economic incentives for food waste reduction, introducing practical strategies with steady enforcement, developing suitable strategies for each generation source, and carrying out a national practice campaign. Several measures have been implemented in this regard since 1996. The achievement of these strategies included promoting the policy of the separate collection of food waste, an increased recycling rate, the reduction of food waste generation, and the spread of an eco-friendly food culture.

The initial municipal solid waste (MSW) recycling policy in Taiwan was established in 1990 [41]. Then, the national government established an EPR system in 1997 that required manufacturers to pay recycling fees based on the material, volume, weight, and value to be recycled. Through recycling and reduction activities, such as volume-based collection fees (2000- in Taipei city); plastic bag use restriction program (2003-) with the goal to reduce the annual production and consumption of plastic bags by 20,000 tons; and a food- and garden-waste recycling programme (2000-); the amount of MSW generated dramatically decreased after 1997 [41]. Resource productivity in Taiwan increased by $54.9 \%$ between 2007 and 2013. Taiwan is shifting its strategy and priority from waste management to sustainable material management (SMM), under the framework of $6 \mathrm{R}$ which includes $5 \mathrm{R}$ $(3 R+$ energy recovery and land reclamation), and Redesign. It is a comprehensive approach that integrates the economy, resources, and environment through database development, networking, and footprint tracking for the management of supply chains, and intends to create closed material loops from source to sink with counter-measures against global resource scarcities, and plans to establish the Cyclic Resources Use Act. SMM is achieved by reductions across the supply chain, a sustainable circulation system of hazardous and non-hazardous substances, and increases in resource productivity.

\section{Methodologies for decision-making}

\section{Material and substance flow analysis}

It is essential to examine the effects of each program or project to identify and implement effective waste prevention policies. Helpful approaches include LCA as well as MFA and substance flow analysis (SFA), which contribute to the visualization of flows, stocks, and balances between various compartments within the system [42-44]. An MFA can also be used for developing indicators to assess resource efficiency and sustainable development [5-9, 44]. These methods are most useful if defined in space and time because they can then be applied to a region, management system, and specific product/treatment methods, such as Ni flow in China [45], Cd flow in MSW in Taiwan [46], $\mathrm{Cd}$ flow in Australia [47], $\mathrm{Pb}$ flow in end-of-life vehicle (ELV) management systems [48], Au flow in Germany and the USA [49], and Zn flow related to electric-arc-furnace dust management [50]. For instance, a study on Cd flows in Australia during 1998-1999 by Kwonpongsagoon et al. [47] revealed that unintentional sources, such as contamination in phosphate fertilizer, are generally greater sources of $\mathrm{Cd}$ than intentional uses, such as $\mathrm{NiCd}$ batteries and pigments. It was also found that atmospheric deposition accounted for $52 \%$ of the total inputs to agricultural soils.

Although the objective of legislation in the EU and other regions is to increase recycling rates, this type of quantitative approach does not consider the presence of unwanted substances; such as recycling loops that contain both valuable and harmful substances [51, 52]. For instance, copper contamination in steel products leads to down-cycling and lowers the quality of recycled products. Therefore, the concepts of "final sink" and "clean cycle" strategies were proposed along with several indicators [51, 53-57]. Here, "final sinks" are defined as "sinks of immobilized materials with a very long residence time ( $>10,000$ years)" [53, 56]. It has been noted that the characteristics of substancespecific sinks should be determined by the biogeochemical properties of the specific substance, and their application and utilization within the anthroposphere must be considered [57]. Based on the MFA, and considering the availability of final sinks, Brunner determined that three types of residues are generated from processes and systems: (1) "clean" waste products suitable for recycling, (2) "sustainable" emissions that do not overload the global cycles of water and air or the capacities of the available final sinks [53], and (3) waste that meets the final storage quality requirements and can be immobilized for long periods when landfilled. He suggested that if no appropriate final sink could be assigned to a material, then that material should be phased out and replaced. 
Fig. 1 Framework of LCA for waste prevention. This figure is made based on Cleary [60], Gentil et al. [61], and Nessi et al. [62]

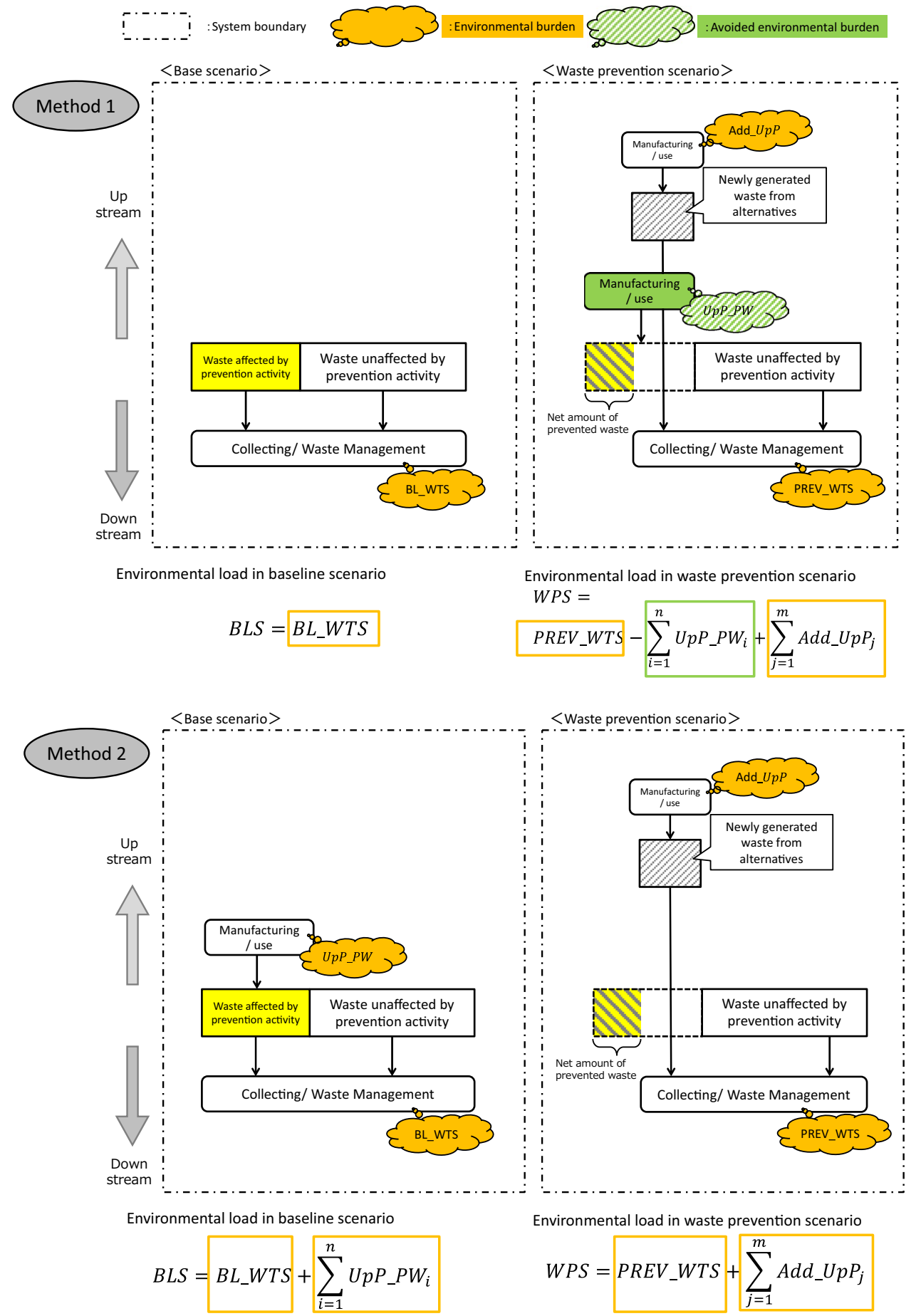

\section{Life-cycle assessment}

Many LCA studies of waste management have been reported globally. Among some 222 published solid waste management studies by Laurent et al. [58], the global distribution of studies was as follows: 33 in Italy, 22 in Spain, 20 in Sweden, and 19 in Denmark. In other regions, there were 12 studies in the USA, 10 studies in China, 6 studies in Japan, and 8 studies in Australia.

Because it is commonly assumed that waste constitutes no burden until it actually becomes waste (the "zero burden" assumption), the system boundary in the LCA studies of waste management generally starts from waste generation [59]. However, to quantify the effects of $2 \mathrm{R}$ activities, improved conceptual models have been proposed [60-62]. 
Cleary proposed expansion of the system boundary to include the production stages of only the products affected by waste prevention activities [60]. Gentil et al. regarded the size of the reduction (i.e. the amount of waste that was prevented) of MSW as virtual waste that needed no treatment and, therefore, caused no environmental burden [61].

Based on Cleary [60], Gentil et al. [61], and Nessi et al. [62], the framework of LCA for evaluating waste prevention activities is illustrated in Fig. 1. In Method 1, the environmental impacts of the upstream (such as the production and use stages) that are related to the waste affected by the prevention activities $\left(U p P \_P W\right)$ are subtracted in the waste prevention scenario as avoided impacts. On the other hand, in Method 2, UpP_PW is included in the base scenario. If some additional environmental impacts from the prevention activities are observed, they must be included in the waste prevention scenario. When calculating the net reduction effect (BLS-WPS), the same result can be observed. Since the conceptual model has been developed, the number of case studies evaluating the effects of $2 R$ has increased, as will be discussed later in this paper.

\section{Multiple-criteria decision making}

In addition to LCA, other decision-making models are also available. Ma reviewed and developed several models to support decision-making in MSW management [63-65]. Multiobjective programing (MOP) has been applied to solve MSW management issues, such as selecting site locations and choosing alternatives and strategies [63-66]. Multi-criteria decision making (MCDM) methods have been applied to choose the best alternative among several choices by considering the number of criteria. There are several MCDM methods available, such as the analytic hierarchy process (AHP) method, the outranking method, and the technique for order preference by similarity to ideal solution (TOPSIS) method. Su et al. applied AHP to evaluate five fly ash management alternatives in Taipei City, Taiwan, while considering the environmental, economic, social, management, and technological aspects [64]. $\mathrm{Su}$ et al. also applied the TOPSIS method to evaluate four waste reduction policies in Taoyuan County, Taiwan, while considering environmental, administrative, economic, and social aspects [65].

\section{Target products and/or materials for waste prevention}

Some target flows have great potential for preventing the misuse of resources and the environment, such as food waste, batteries, and various parts of end-of-life vehicles. In this section, we consider the products and materials that are now widely investigated around the globe. We also include materials that we consider it necessary to investigate, and introduce some case studies.

$M S W$

Gentil et al. [61] conducted an LCA that considered three types of waste prevention in MSW, specifically unsolicited mail, beverage packaging, and food waste, and the weight reduction was assumed to be 60,20 , and 20 , respectively. The benefits of prevention were significantly higher in the upstream (production) than that in the downstream (waste management) parts of the life cycle. Of the three prevention measures, food waste prevention showed the highest benefits. Similarly, Cleary conducted an LCA to evaluate five waste prevention activities (WPAs) in Toronto, Canada, which contributed to a $3.6 \%$ reduction in the MSW generation in 2008. The five activities were as follows: (1) reduction of unaddressed advertising mail, (2) reuse of disposable carry-out plastic bags, (3) substitution of articles available online, (4) lightweight and refillable wine/spirit glass bottles, and (5) grass cycling [67]. It was revealed that, although the total amount of MSW prevented by the five WPAs was only $3.6 \%$, the endpoint impacts (ecosystem quality, human health, natural resources) in the upstream improved by up to four times. Regarding the life-cycle environmental impacts (midpoint level), the top three impacts reduced by the five WPAs were freshwater eutrophication, ozone depletion, and natural land transformation.

\section{Food loss}

Although the definition of food loss differs between countries and regions $[4,68-70]$, it generally refers to the portion of food waste which can be avoided by careful attention. Food loss is a representative prevention target about which many reports and academic papers have been published. Table 2 summarizes some of the previous studies with quantitative results related to the current situation, and the prevented effects on waste generation, environmental impacts, and economic aspects (see electronic supplemental materials SI2 for detailed list). According to the Food and Agriculture Organization (FAO) of the United Nations, global food waste annually accounts for approximately 1.3 billion tons of waste, and one-third of all food produced is wasted [68]. Munesue et al. estimated that a $50 \%$ reduction in food loss and waste in the food industry in developed countries would have accounted for 0.6-9.5\% of the domestic regional supply of these products in 2007 [71]. To clarify the current situation in the household, retail and food service sectors, and several specific companies, field surveys such as waste composition analyses and other measurement surveys (e.g. questionnaires and statistics) were conducted [72-75]. For instance, a household waste 


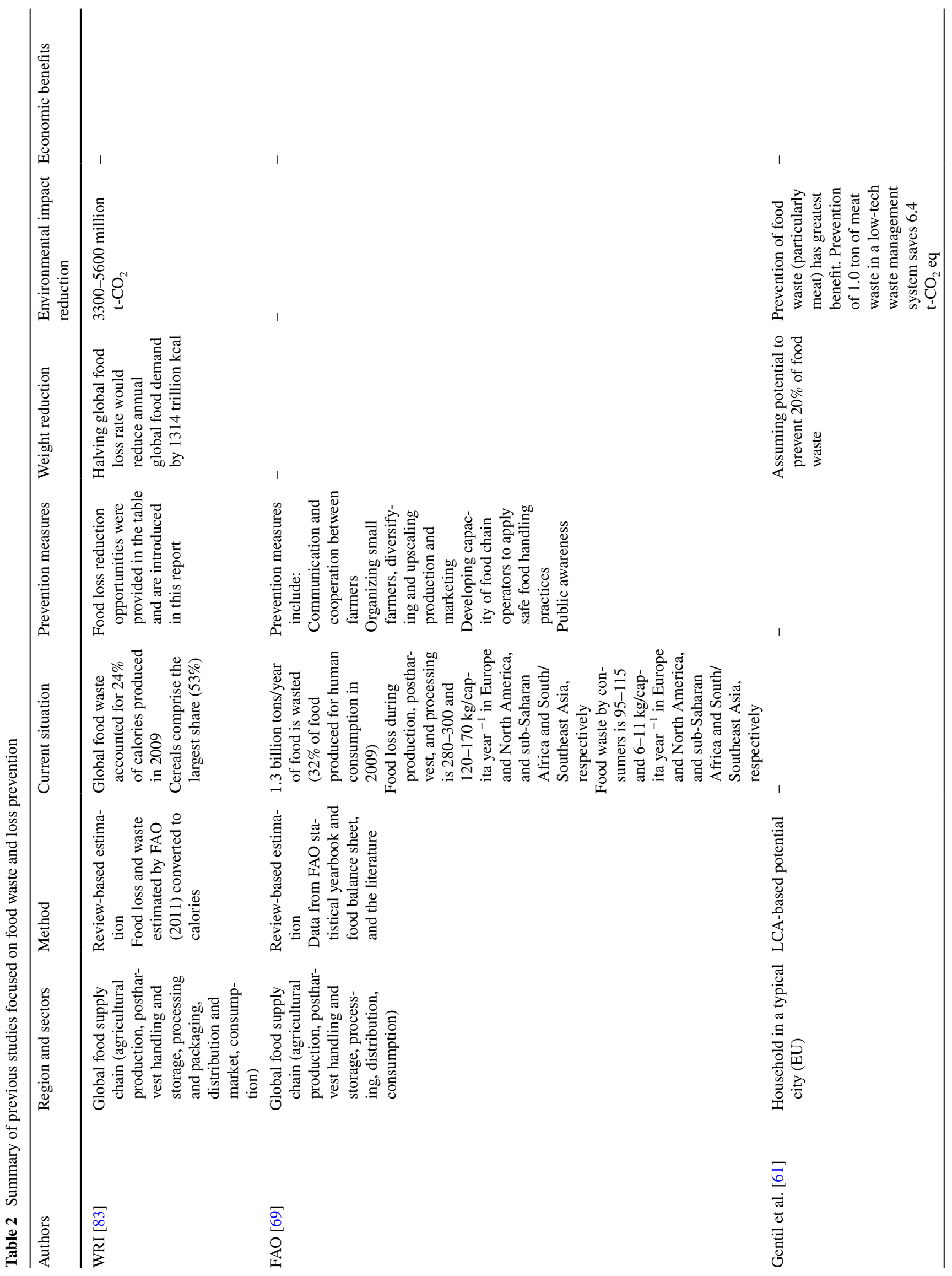




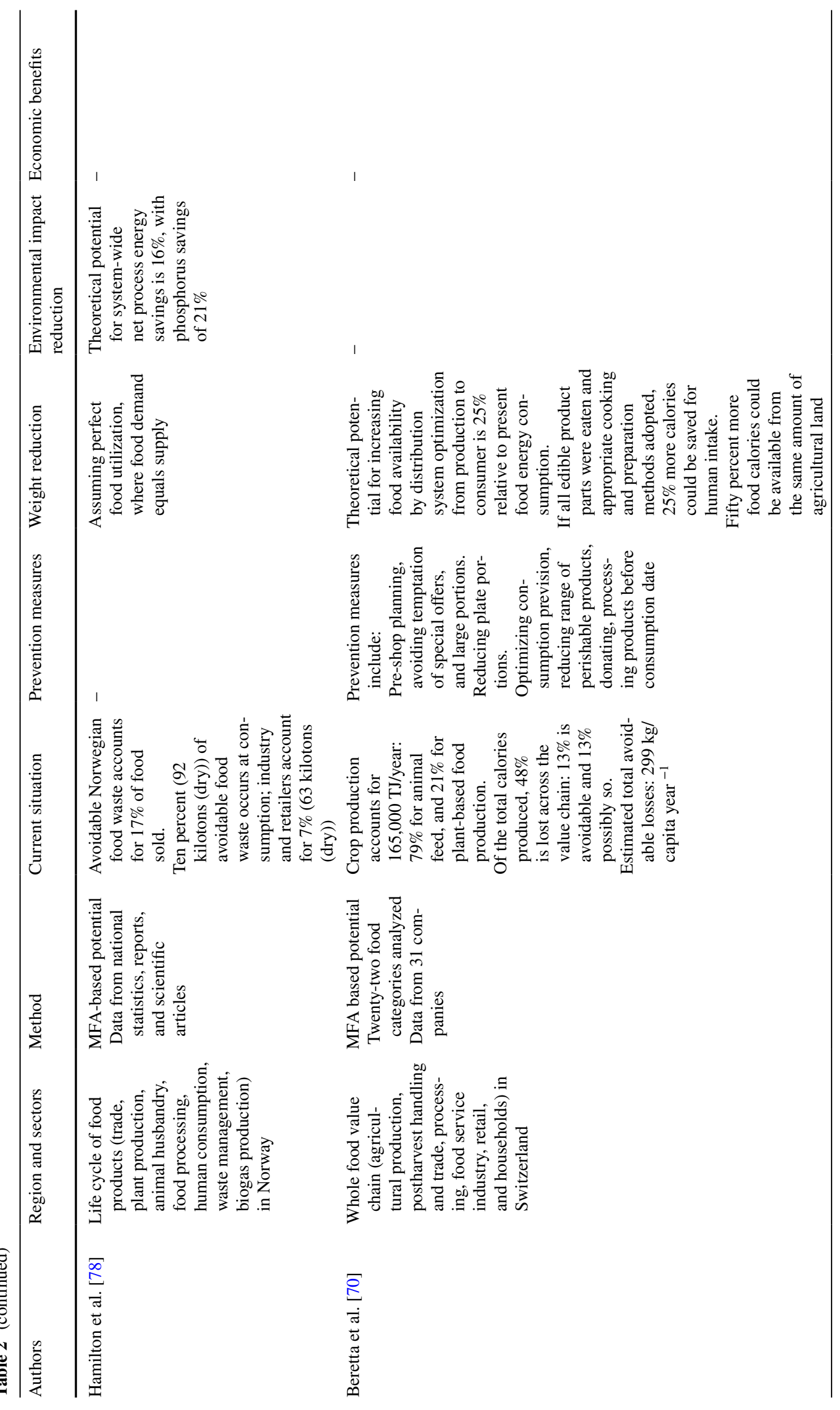




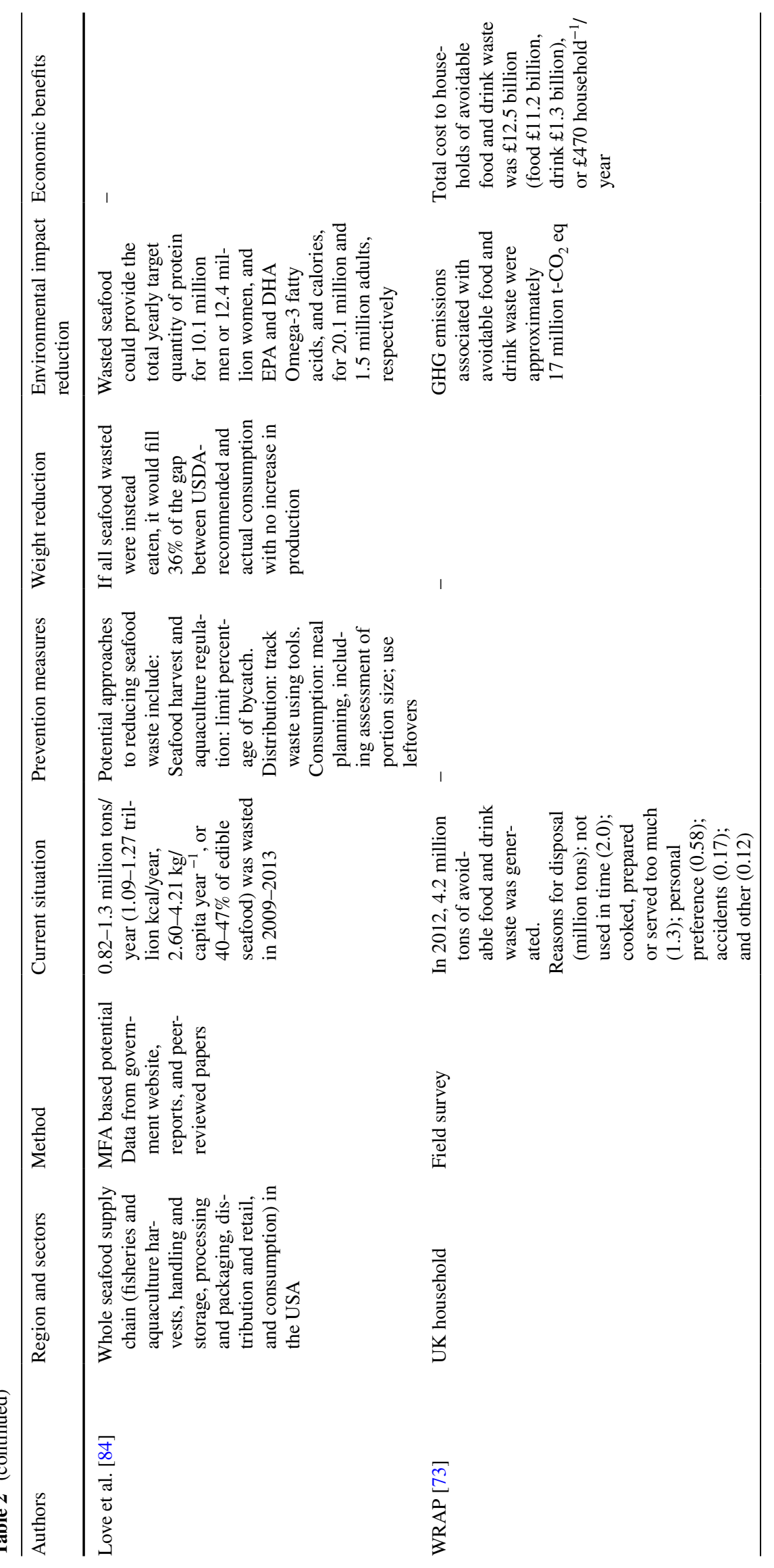




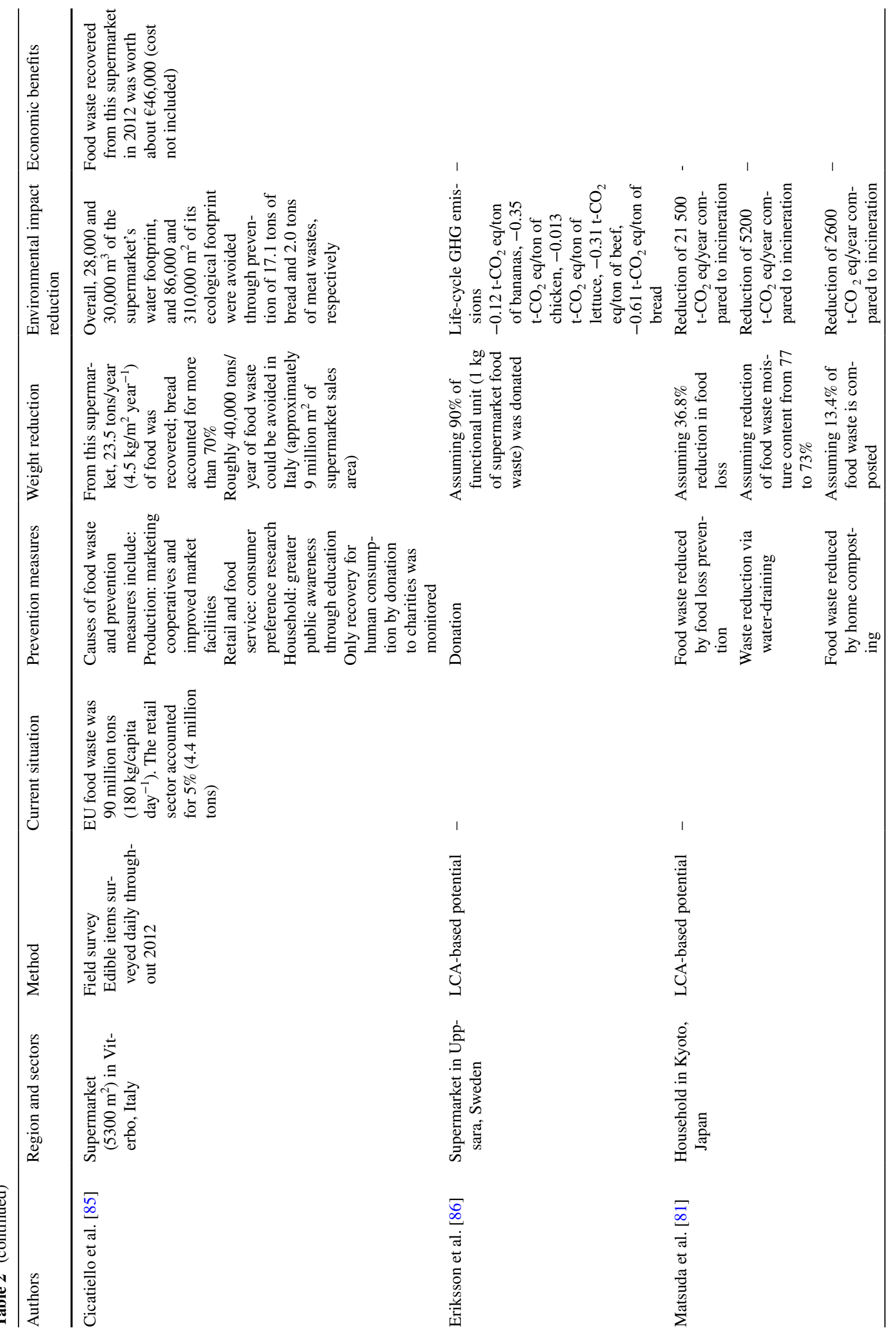




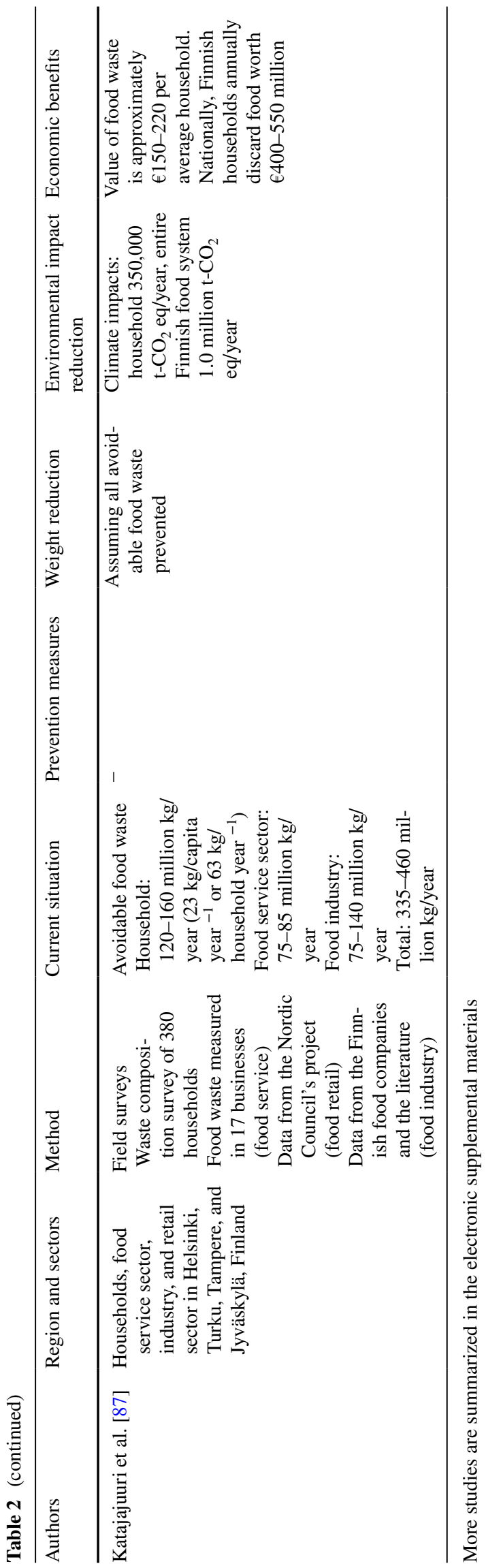

composition survey in the UK by the Waste and Resources Action Programme (WRAP) revealed that the amount of avoidable food and drink waste generated was 4.2 million tons/year as of 2012, which resulted in the emission of 17 million t- $\mathrm{CO}_{2}$ eq at a cost of 12.5 billion euro [73]. This total included 2.0 million tons/year of avoidable food waste from products not consumed by their respective due dates. Statistical analyses were also performed for retail in Austria [76] and one hospital in Portugal [77]. MFA was employed to describe the flow of the food supply chain $[70,78]$, and Beretta et al. revealed that $48 \%$ of the total calories from foods were lost across the whole food value chain [70]. Of course, there are many LCA studies focused on evaluating the prevention effects, as discussed later.

It has often been pointed out that the environmental impact from the production of animal-based food (such as meat) is greater than that from vegetable food plant production $[61,79,80,82]$. Therefore, the composition of the food lost should be identified through waste composition surveys to quantify the effects generated from the reduction of food loss. This is also a good idea because the effects from the reduction of food loss differ according to the type of food loss reduced, as do the best ways to reduce it [81].

Food waste generation in Germany was 11 million tons/ year. Food consumption at home and away from home accounted for $457 \mathrm{~kg} / \mathrm{capita}$ and $70 \mathrm{~kg} / \mathrm{capita}$, respectively [79], of which, $16.6 \%$ (76 kg/capita) and $33.5 \%$ (23.6 kg/ capita), respectively, was wasted. In other words, from the viewpoint of life-cycle GHG emissions, 2,270 $\mathrm{kg}-\mathrm{CO}_{2} \mathrm{eq}$ was derived from food that was eaten, while $476 \mathrm{~kg}-\mathrm{CO}_{2} \mathrm{eq}$ was lost to food waste. The amount of agricultural land used globally for German food consumption accounted for $60 \%$ of Germany's land area. It was revealed that for 10 impact categories (e.g., global warming, water use, land use, etc.), 13-20\% of the environmental impacts of food consumption in Germany were attributable to food loss occurring in the various supply chains.

By way of a scenario analysis in Kyoto, Matsuda et al. [81] estimated the reduction effects of life-cycle GHG emissions by three household food waste prevention activities: preventing edible food loss, draining moisture, and home composting. Their study computed the volume of waste that was prevented, but also noted that the method of prevention significantly affected the results.

Martinez-Sanchez et al. evaluated the environmental life-cycle costing (E-LCC) and societal life cycle costing (S-LCC) of four food waste management programs including the food waste prevention costs [82]. As show in Fig. 2, regarding the direct effects, the results of the environmental part of the E-LCC and S-LCC showed that the waste prevention scenario was much lower than those for the scenarios without waste prevention because food production was avoided. On the other hand, while 


\section{A Environmental part of E-LCC (LCA )}

Direct effects:
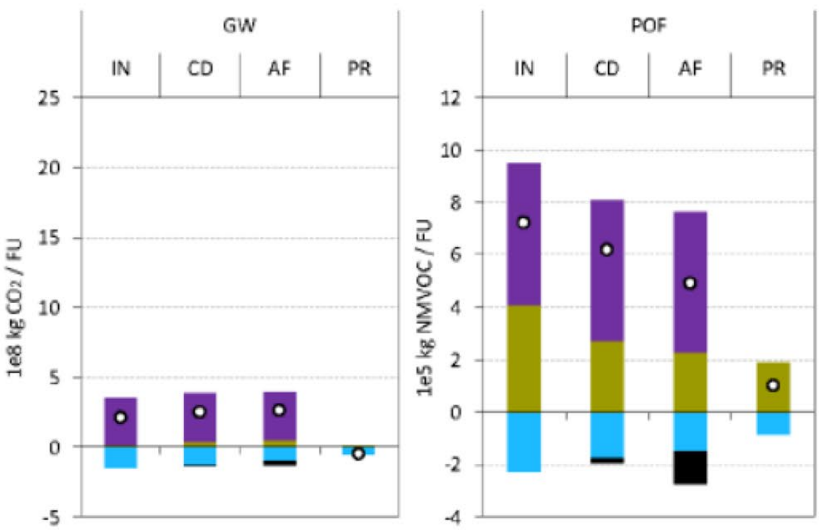

Total effects (direct + indirect):
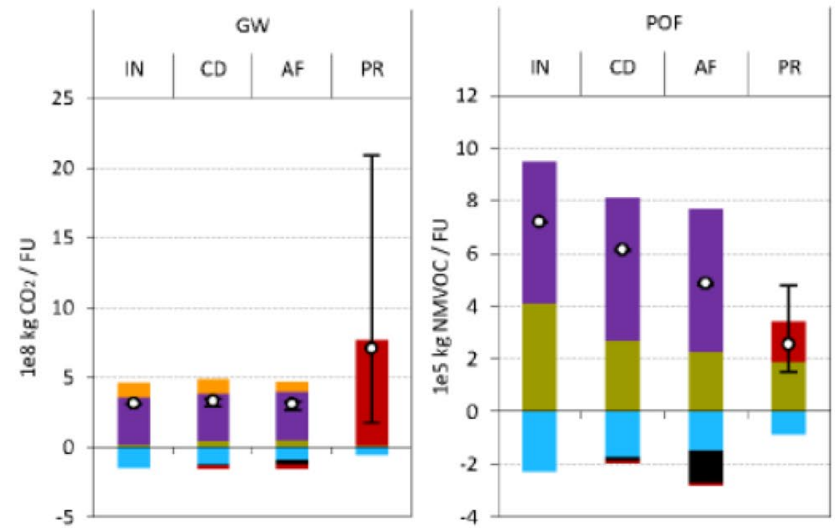

B S-LCC

Direct effects:

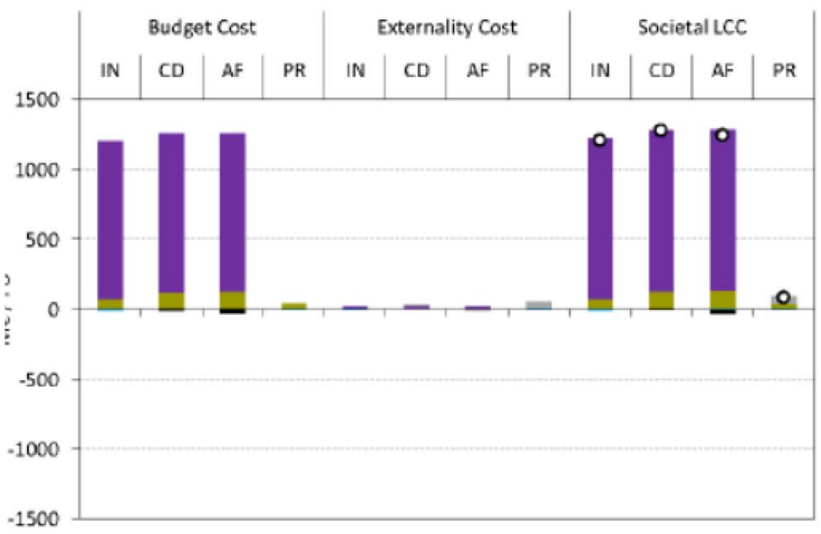

Total effects (direct + indirect):

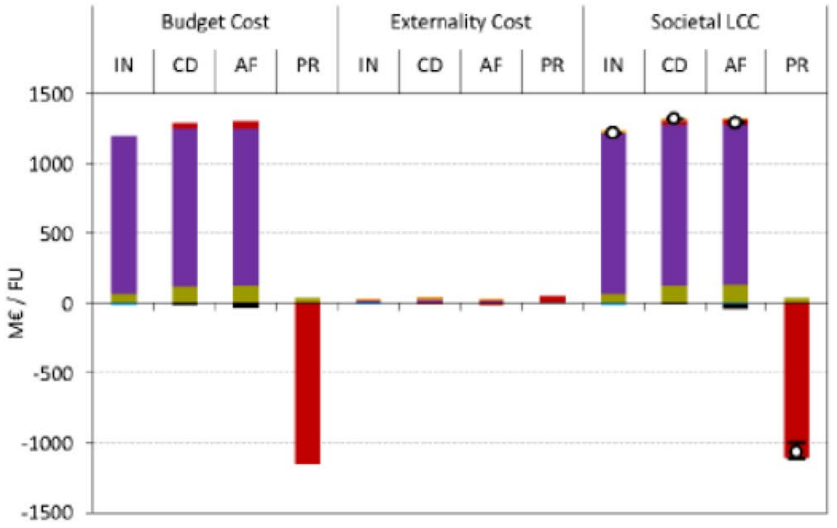

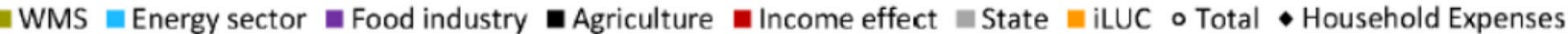

Fig. 2 Results of E-LCC and S-LCC of food waste management by Martinez-Sanchez et al. [82]. $F U$ functional unit, $G W$ global warming, $P O F$ photochemical ozone formation, NMVOC non-methane volatile organic carbon compound, $I N$ incineration as MSW, $C D$ co-

considering the indirect effects, the results differed between the E-LCC and S-LCC. The indirect effects considered by Martinez-Sanchez et al. included (1) income effects (also called "rebound effects") associated with the marginal consumption induced or reduced, and (2) indirect land-use changes induced by the production of food commodities. These results indicated that if the money saved from unpurchased (prevented) food commodities was used to purchase other goods/services, prevention could sometimes appear to be environmentally worse than business as usual. digestion with manure, $A F$ animal fodder, $P R$ prevention of $100 \%$ edible food waste, WMS waste management sector, $i L U C$ indirect land-use change

\section{Packaging waste}

A reduction of beverage packaging by $20 \%$ was evaluated by Gentil et al. [61] as one of the three prevention measures previously mentioned. Using an LCA, Nessi et al. [88] compared public tap water and refillable bottled water with one-way bottled water as a baseline. They also evaluated the effects of preventing waste generation and reducing environmental impacts through detergent (laundry detergents, fabric softeners and hand dishwashing detergents) distribution (see Fig. 3) [89], and the viability of refillable containers and self-dispensing systems was compared with a single-use scenario (baseline). They showed that five uses of self-dispensing systems allowed lower waste 
Fig. 3 Relationship between number of uses of refillable containers and climate change, compared with the range for single-use ones. Case study of laundry detergent by Nessi et al. [89]. Functional unit of the study was the distribution of 1000 litres of detergent nearby a retail outlet of the large-scale retail trade in Italy

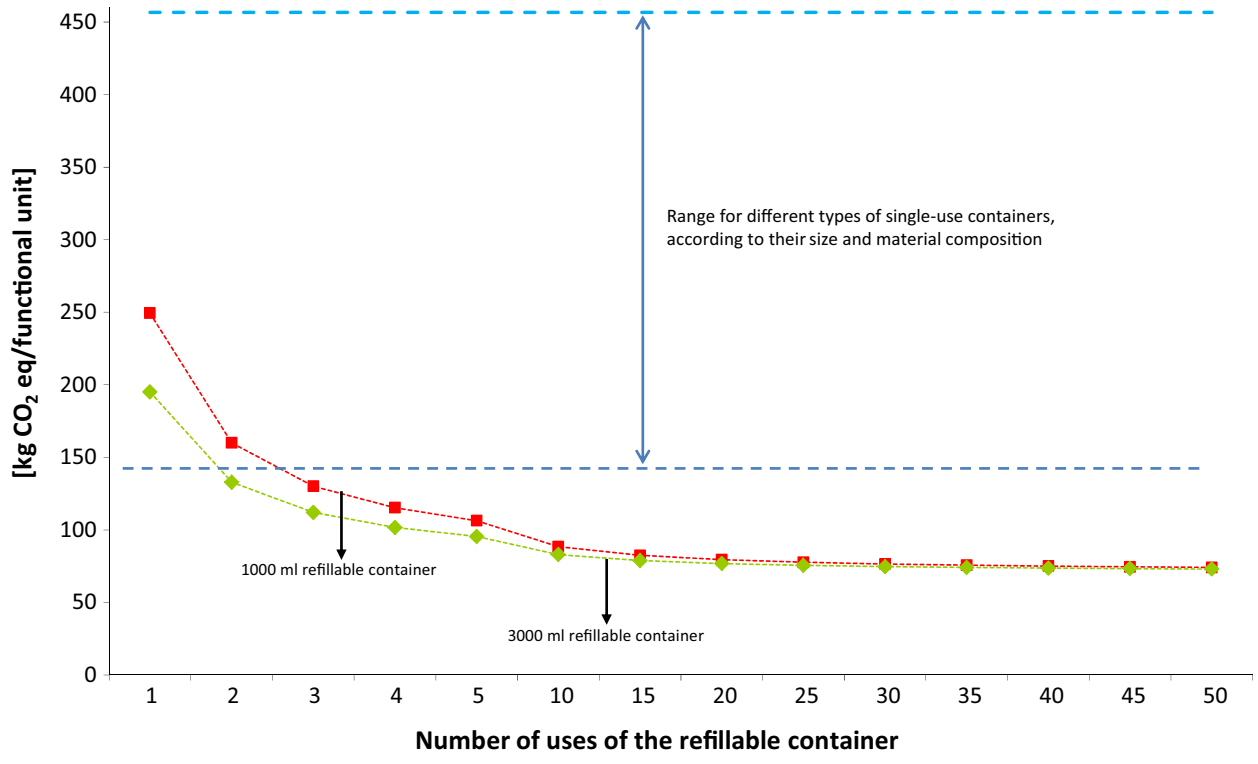

generation and environmental impacts than did single-use containers. Then, Nessi et al. evaluated the potential effects of implementing these two packaging waste prevention activities on the overall waste management system in the Lombardia Region of Italy as of 2020 [90]. It was calculated that $0.66 \%$ of MSW generation could be reduced by the adoption of these two prevention activities, and that a much greater reduction of environmental impacts could be achieved. Among 14 impact categories, the improvements ranged from a $4.4 \%$ reduction of water resource depletion to a $25.0 \%$ reduction of terrestrial eutrophication, compared with the baseline scenario without waste prevention. It was found that half of the impact categories could be reduced by $15-25 \%$, and it was also pointed out that the upstream impacts were greater than the downstream impacts. Of the two prevention activities, the utilization of public tap water showed a higher reduction potential of environmental impacts than did the detergent distribution through self-dispensing systems. A $0.5 \%$ reduction of waste from the former activity (tap water utilization) reduced 11 of 14 impact categories by 5-23\%. LCA by Dolci et al. [91] compared traditional (single-use) and self-dispensing systems (so called "loose distribution") of dry food products (pasta, breakfast cereals, and rice) to evaluate the effects on waste generation and environmental impacts by packaging prevention; however, the results significantly differed between the products. For breakfast cereals and rice, the loose distribution system contributed to a reduction in the waste generated as well as most of the environmental impacts. On the other hand, waste generation increased by up to $15 \%$ for pasta when compared with single-use polypropylene, while it decreased by $50 \%$ compared with single-use carton-board boxes. It was pointed out that the results were dependent on how the traditional and the loose distributions were implemented. If the size and material of the packages were very similar, the loose distribution system might fail in reducing the waste generated and the environmental impacts thereof.

\section{Battery, E-waste, and ELV}

End-of-life primary batteries are a representative example of hazardous waste. Historically, there have been concerns about the environmental pollution derived from the $\mathrm{Hg}$, $\mathrm{Cd}$, and $\mathrm{Pb}$ contained in end-of-life batteries. To reduce the generation of end-of-life batteries, it is important to advocate for their replacement with secondary (rechargeable) batteries. On the other hand, without proper management, the increasing number of end-of-life secondary batteries is also causing issues related to the associated environmental risks [92]. Secondary batteries consume scarce metals. For example, NiMH batteries contain $\mathrm{Ni}$ and $\mathrm{Co}$, and Li-ion batteries contain Li and Co. Because secondary batteries have been recently introduced for various uses, such as small home appliance products, hybrid electric vehicles (HEVs), electric vehicles (EVs), and photovoltaic power generation systems, the resource management of batteries is becoming a more significant issue.

To provide an understanding of a desirable management system, many SFA and LCA studies have been conducted. For example, Dolci et al. [93] used an LCA to compare the use of disposable alkaline batteries to that of secondary NiMH ones, while specifically considering the AA and AAA sizes. They found that the number of times that rechargeable batteries were used is a key factor when determining their environmental impact and energy performance, and at least 50 charge cycles were required for a robust reduction of impacts. High-consumption devices, 
such as digital cameras and electronic toys, are the most appropriate use for rechargeable batteries.

The Bio Intelligence Service compared three secondary types of batteries, namely $\mathrm{NiCd}, \mathrm{NiMH}$, and $\mathrm{Li}$-ion $\left(\mathrm{LiFePO}_{4}\right)$, used in cordless power tools in a case study [94]. An LCA was conducted to compare the environmental impacts of the three types of batteries and identify the impact hotspot in the life-cycles of the batteries. The result was that there were no clear advantages identified between the types batteries. Regarding natural resources, the $\mathrm{NiCd}$ batteries were thought to have a potentially lower metal depletion impact on resources than that for the NiMH and $\mathrm{LiFePO}_{4}$ batteries in the mid-term; while both the NiMH and $\mathrm{LiFePO}_{4}$ batteries had a potentially lower abiotic resource depletion impact than that for the $\mathrm{NiCd}$ batteries over the long term. These results implied that the pertinent time horizon is another significant factor that should be considered.

It was estimated that 20-50 million tons/year of WEEE are generated globally [95] and this amount has been increasing. For instance, the generation of household WEEE in Europe is projected to grow annually at 2.5-2.7\% [96]. Since WEEE contains a variety of both toxic and valuable substances, its management requires significant effort. Chancerel and Rotter [97] estimated that approximately 5000 tons/year and 16,000 tons/year of end-of-life mobile phones were generated as of 2007 in Germany and the USA, respectively. Of the amount of Au contained in this waste (350-500 $\mathrm{Kg}-\mathrm{Au})$, less than $5 \%$ was recovered, $3 \%$ was reused, and $92 \%$ was lost. While end-of-life mobile phones and PCs accounted for $0.5 \%$ and $17 \%$, respectively, of the total generation of WEEE (categories 2, 3, 4, 6, and 7 defined in the WEEE Directive [98]), they accounted for $40 \%$ of all the Au contained in WEEE. Similarly, high percentages of other valuable metals are discarded: $88 \%$ of Pd, $89 \%$ of $\mathrm{Ag}$, and $89 \%$ of Ni [99]. An LCA study by Eygen estimated that recycling desktop and laptop PCs could reduce natural resource consumption by 80 and $87 \%$, respectively, compared with landfilling [100]. Regarding the recovery of metals, the compromise between grade (quality) and recovery (quantity) should be of another concern [101, 102]. Bovea et al. investigated the reusability of WEEE from a collection campaign of households in Castellon de la Plana, Spain [103]. Among the $87.7 \mathrm{~kg}$ (96 units) of samples, 67.7 and $2.1 \%$ were considered as potentially reusable and directly reusable, respectively. On the other hand, an interview survey of 28 reuse organizations around the world pointed out that (1) the access to sufficient volumes, (2) informal and illegal reuse practices, (3) regulations, standards, and product design, and (4) costs, as barriers for promoting the reuse of WEEE [104].

Worldwide automobile ownership exceeded 1.1 billion vehicles in 2010 [105], and it has been estimated that end-of-life vehicles (ELVs) accounted for $4 \%$ of the total ownership, or 40 million vehicles, of which 12.0 million were in the USA, 7.4 million in the EU, 3.5 million in China, and 3.0 million in Japan) [106, 107]. From the viewpoint of hazardous materials, heavy metals contained in ELVs are historically one of the most important issues for ELV management systems, which includes automobile shredder residue (ASR) treatment. In Japan, the Japan Automobile Manufacturers Association, Inc. (JAMA) set a voluntary target to reduce the $\mathrm{Pb}$ content in the components of passenger vehicles (except for the lead-acid battery) by more than $90 \%$ by 2006 , compared to the total content in 1996 of $1850 \mathrm{~g}-\mathrm{Pb}$ per vehicle [48]. Although the $\mathrm{Pb}$ content per vehicle was successfully reduced by up to $100 \mathrm{~g}-\mathrm{Pb}$, it was pointed out that it will take some time for this reduction to influence the $\mathrm{Pb}$ content in ELVs and ASR [48]. The toxic chemicals, such as brominated flame retardants (BFRs), that are contained in ELVs have also become global concerns [106, 108]. In addition to their levels of toxicity, the need to develop resource recovery methods has become more important because electric devices and next-generation vehicles (such as HEVs and EVs) are becoming increasingly popular. The amount of scarce metals contained in an ELV has been quantified using various approaches, including dismantling surveys [107, 109-115].

\section{Construction and demolition waste}

C\&D waste is often one of the top three priority waste-prevention areas because it is expected to significantly reduce life-cycle environmental impacts [12, 13, 23]. Several summary reports, guidelines, and reviews related to C\&D waste management, best practices, and LCAs have been published [116-123]. Approximately 1 billion tons of C\&D waste, one-third of the total waste generation, was annually generated in the EU as of 2006 [116]. C\&D waste consists of recyclable materials, such as concrete, bricks, gypsum, wood, glass, and so on. Wang et al. evaluated reconstruction and extension projects for overpasses in Shanghai city, China, through a life-cycle inventory analysis [124], which revealed that using regenerated aggregate could reduce energy consumption and GHG emissions by 45.3 and $43.9 \%$, respectively, compared with using virgin materials. Due to its longer lifespan, life-cycle thinking, including the design stage, is highly relevant $[125,126]$. Source segregation is important for promoting recycling and the reduction of environmental impacts [120, 122]. However, when $C \& D$ materials are recycled, potential contamination with hazardous compounds may be involved. For example, construction materials are the most common asbestos-containing products [127]. Butera et al. reported that PCBs and PAHs were detected in all $33 \mathrm{C} \& \mathrm{D}$ waste samples [128]. An LCA revealed that the recycling of C\&D waste showed 
fewer environmental impacts than did landfilling [122]. On the other hand, it was also pointed out that the fate of $\mathrm{Cr}$ in the subsoil greatly influenced the results; therefore, identifying the status of the contaminants emitted (like $\mathrm{Cr}$ ) in the subsoil was important [129].

\section{Persistent chemicals and hazardous compounds}

Despite the development of regulations, persistent chemicals, such as PCBs, BFRs, and hazardous compounds, were and still are contained in different products in use for various purposes [130]. They are released into the environment from various sources and life stages: in the use stage of the product, including in the dust [131-133], in the treatment stage in recycling facilities [134-140], and in landfill sites [141-143]. Mizouchi et al. revealed that BFRs and phosphorus flame retardants (PFRs) were detected in all of the dust samples gathered from elementary schools (18 samples) and domestic houses (10 samples) in Japan in 2009 and 2010. The concentration (ng/g dry weight) ranged from 260 to 9300 for $\sum$ BFRs and $9300-5,500,000$ for $\sum$ PFRs . According to the multimedia urban model on the fate of polybrominated diphenyl ether (PBDE) in Toronto, inadvertent ingestion of house dust is the largest exposure pathway for all human life stages except in infants [144].

As the flow of products, materials, and waste has become global due to its legal and illegal transport, the persistent chemicals and hazardous compounds contained within them are also transferred globally. Improper recycling results in negative impacts on the environment and on human health [134-136, 138, 139, 145]. In the case study in Bui Dau [138], northern Vietnam, higher contamination (up to $14,000 \mathrm{ng} / \mathrm{g}$-dry) by flame retardants and some persistent organic pollutants could be observed in surface soils and river sediments near the e-waste recycling workshops or open burning sites, while low concentrations (up to $10 \mathrm{ng} / \mathrm{g}$-dry) were found in the soils from footpaths around rice paddies. The contamination was reduced along the stream in the downstream sediments. As of 2010 and 2011, when comparing human serum from workers at e-waste recycling sites with that from residents in rural areas, the levels of PCB, hydroxylated PCB, PBDE, and bromophenol concentrations in the former were significantly higher due to their occupationally related exposure [139].

\section{Conclusions}

This paper provides a summary of the information obtained through the workshop held in Kyoto, Japan, during 11-13 November 2015, which included invited experts and researchers from a number of countries in charge of waste prevention and $3 \mathrm{R}$ policies in several countries, and includes an additional review of 240 previous studies on the topic. The achievements of this study are summarized as follows:

- Regarding policy development, a decoupling between environmental pressures and economic growth was recognized as an essential step towards a sustainable society in each country. It is expected that $3 \mathrm{R}$ and resource management policies, including waste prevention, will play a crucial role. Some good practices at the national and regional scales have already been demonstrated.

- Methodologies for decision-making have been developed step by step. Approaches using material/substance flow analysis (MFA and SFA) have become sophisticated enough to describe the fate of resources and/or hazardous substances based on human activity and the environment, including the final sink. An LCA has also been developed to evaluate waste prevention activities. These methodologies can be combined with each other or with other methodologies to consider multiple criteria, such as economic and social aspects.

- To effectively promote waste prevention, target products have been identified with higher priority. Food loss is one of the waste fractions with the highest priority because the corresponding countermeasures have significant upstream and downstream effects. On the other hand, concerns about rebound effects after waste prevention is achieved, have started to be considered. Persistent organic pollutants and hazardous compounds should also be considered in the situation where recycling activities are globally widespread for the promotion of a material-cycling society.

Acknowledgements This research was supported by the Environment Research and Technology Development Fund, Grant Number 3K153001, from the Ministry of the Environment, Japan.

Open Access This article is distributed under the terms of the Creative Commons Attribution 4.0 International License (http:// creativecommons.org/licenses/by/4.0/), which permits unrestricted use, distribution, and reproduction in any medium, provided you give appropriate credit to the original author(s) and the source, provide a link to the Creative Commons license, and indicate if changes were made.

\section{References}

1. Sakai S, Yoshida H, Hirai Y, Asari M, Takigami H, Takahashi S, Tomoda K, Peeler MV, Wejchert J, Schmid-Unterseh T, Douvan AR, Hathaway R, Hylander LD, Fischer C, Oh G-J, Jinhui L, Chi NK (2011) International comparative stud of 3R and waste management policy developments. J Mater Cycles Waste Manag 13:86-102 
2. Yoshida H, Shimamura K, Aizawa H (2007) 3R strategies for the establishment of an international sound material-cycle society. J Mater Cycles Waste Manag 9:101-111

3. Ministry of the Environment, Japan. Website. Regional 3R Forum in Asia and the Pacific. https://www.env.go.jp/recycle/3r/ en/index.html. Accessed 31 May 2016

4. Yano J, Sakai S (2015) Waste prevention indicators and their implications from life cycle perspective: a review. J Mater Cycles Waste Manag 18(1):38-56

5. OECD (2008) Measuring material flows and resource productivity Synthesis report. OECD, Paris

6. OECD (2011) Resource productivity in the G8 and the OECD-a report in the framework of the Kobe 3R action plan.

7. OECD (2015) OECD green growth studies material resources, productivity and the environment

8. UNEP (2011) Decoupling natural resource use and environmental impacts from economic growth, a report of the working group on decoupling to the international resource panel. Fischer-Kowalski M, Swilling M, von Weizsäcker EU, Ren Y, Moriguchi Y, Crane W, Krausmann F, Eisenmenger N, Giljum S, Hennicke P, Kemp R, Lankao PR, Manalang ABS, Sewerin S

9. UNEP (2014) Decoupling 2: technologies, opportunities and policy options. A report of the working group on decoupling to the international resource panel. von Weizsäcker EU, de Larderel J, Hargroves K, Hudson C, Smith M, and Rodrigues M

10. EC (2005) Communication from the Commission to the Council, the European Parliament, the European Economic and Social Committee and the Committee of the Regions-Taking sustainable use of resource forward-a thematic strategy on the prevention and recycling of waste. COM/2005/0666 final

11. EU (2008) DIRECTIVE 2008/98/EC OF THE EUROPEAN PARLIAMENT AND OF THE COUNCIL of 19 November 2008 on waste and repealing certain Directives (Text with EEA relevance). http://eur-lex.europa.eu/legal-content/EN/ TXT/?uri=CELEX:32008L0098. Accessed 23 Jan 2015.

12. Reisinger H, van Acoleyen M, O'Connor C, Hestin M, Laureysens L, Morton G, Dolley P, Nelen D, Vanderreydt I (2011) Evolution of (bio-) waste generation/prevention and (bio-) waste prevention indicators Final Report, A project under the Framework contract ENV. G. 4/FRA/2008/0112.

13. Watson D, Milios L, Bakas I, Herczeg M, Kjær B (CRI), Tojo N (IIEEE) (2013) Proposals for targets and indicators for waste prevention in four waste streams. Nordic Council of Ministers, Copenhagen

14. EC (2012) Preparing a Waste Prevention Programme-Guidance document.

15. European Environment Agency (EEA) (2015) Waste prevention in Europe-the status in 2014. EEA, Copenhagen

16. EIONET website, Quantitative targets. http://scp.eionet.europa. eu/facts/WPP. Accessed 13 Jan 2015.

17. European Environment Agency (EEA) (2014) Waste prevention in Europe-the status in 2013. EEA, Copenhagen

18. EC (2010) Communication from the commission. 'Europe 2020. A strategy for smart, sustainable and inclusive growth'. COM (2010) 2020 final.

19. EC (2011) Communication from the Commission to the European Parliament, the Council, the European Economic and Social Committee and the Committee of the Regions 'A resource-efficient Europe-Flagship initiative under the Europe 2020 Strategy'. COM (2011) 21 final.

20. EC (2011) Communication from the Commission to the European Parliament, the Council, the European Economic and Social Committee and the Committee of the Regions 'Roadmap to a Resource Efficient Europe. COM (2011) 571 final.

21. EU (2013) Decision No 1386/2013/EU of the European Parliament and of the Council of 20 November 2013 on a General
Union Environment Action Programme to 2020 'Living well, within the limits of our planet' (Text with EEA relevance). L $354 / 171$.

22. EU (2014) Scoping study to identify potential circular economy actions, priority, sectors, material flows and value chains. Final report. Funded under DG Environment's Framework contract for economic analysis ENV.F.1/FRA/2010/0044.

23. EC (2014) Communication from the Commission to the European Parliament, the Council, the European Economic and Social Committee and the Committee of the Regions 'Towards a circular economy - a zero waste programme for Europe.' COM (2014) 398 final.

24. EC (2015) Communication from the commission to the European Parliament, the Council, the European economic and social committee and the committee of the regions. Closing the loop - an EU action plan for the circular economy. Brussels, 2.12.2015, COM (2015) 614 final.

25. Federal Ministry for the Environment, Nature Conservation, Nuclear, Safety (2013) Circular Economy Act. http:// www.gesetze-im-internet.de/krwg/. Accessed 28 Mar 2016 (in Germany)

26. Federal Ministry for the Environment, Nature Conservation and Nuclear, Safety (2013) Waste Prevention Programme of the German Government with the Involvement of the Federal Länder. http://www.bmub.bund.de/fileadmin/Daten_BMU/ Pools/Broschueren/abfallvermeidungsprogramm_en_bf.pdf. Accessed 28 March 2016

27. The Danish Government (2013) Denmark without waste. Recycle more lincinerate less.

28. Italian Ministry of the Environment (2013), Decree October 7th on the adoption of the National Waste prevention Programme. http://www.minambiente.it/sites/default/files/archivio/comunicati/Programma\%20nazionale\%20prevenzione\%20rifiuti.pdf. Accessed 20 June 2016 (in Italian)

29. MOE, Japan (2000) Basic Act on Establishing a Sound Material-Cycle Society. http://www.japaneselawtranslation.go.jp/ law/detail/?id $=2042 \& v m=04 \& \mathrm{re}=01 \&$ new $=1 . \quad$ Accessed: 2015-January-9.

30. MOE, Japan (2013) Fundamental plan for establishing a sound material-cycle society. https://www.env.go.jp/en/focus/docs/ files/20131018-79.pdf. Accessed 13 Jan 2015

31. MOE, Japan (2005) Fundamental plan for establishing a sound material-cycle society. https://www.env.go.jp/en/recycle/ smcs/f_plan.pdf. Accessed 13 Jan 2015.

32. Government of Japan (2008) Fundamental plan for establishing a sound material-cycle society (Tentative translation by Ministry of the Environment). http://www.env.go.jp/en/recycle/ smcs/2nd-f_plan.pdf. Accessed 13 January 2015.

33. Takiguchi H, Takemoto K (2008) Japanese $3 R$ policies based on material flow analysis. J Ind Ecol 12(5-6):792-798.

34. MOE, MAFF, Japan (2013) Law for Promotion of Recycling and Related Activities for the Treatment of Cyclical Food Resources. http://law.e-gov.go.jp/htmldata/H12/H12HO116. html. Accessed 26 Jan 2015 (in Japanese).

35. Kyoto city (2015) The fundamental plan for promoting a SoundMaterial Cycle Society in Kyoto 2015-2020 (in Japanese).

36. Ministry of Environment, Korea (2015) Republic of Korea 2015.

37. Park S, Lah TJ (2015) Analyzing the success of the volumebased waste fee system in South Korea. Waste Manag (Oxford) 43:533-538

38. Yoo K-Y, Yi S (2015) Evaluation and development of solid waste management plan: a case of Seoul for past and future 10 years. J Mater Cycles Waste Manag 17:673-689

39. Ministry of Environment, Korea. ECOREA. Environmental review 2015, Korea 
40. The Committee of Green Growth (2010) Comprehensive strategies for food waste prevention (in Korean)

41. Lu L-T, Hsiao T-Y, Shang N-C, Yu Y-H, Ma H-W (2006) MSW management for waste minimization in Taiwan: the last two decades. Waste Manag (Oxford) 26(6):661-667

42. Brunner PH, Rechberger H (2004) Practical handbook of material flow analysis. Lewis Publishers, Florida

43. Brunner PH, Ma H-W (2009) Substance flow analysis: an indispensable tool for goal-oriented waste management. J Ind Ecol 13(1):11-14

44. Huang C-L, Vause J, Ma H-W, Yu C-P (2012) Using material/ substance flow analysis to support sustainable development assessment: a literature review and outlook. Resour Conserv Recycl 68:104-116

45. Huang C-L, Vause J, Ma H-W, Li Y, Yu C-P (2014) Substance flow analysis for nickel in mainland China in 2009. J Clean Prod 84:450-458

46. Lu L-T, Yu Y-H, Shang N-C, Yang Y-M, Ma H-W, Chen L-J, Hsiao T-Y (2006) Material flow analysis of cadmium applied to review MSW treatment in Taiwan. J Chin Inst Eng Trans Chin Inst Eng Ser A/Chung-kuo Kung Ch'eng Hsuch K'an 29:769-775

47. Kwonpongsagoon S, Waite DT, Moore SJ, Brunner PH (2007) A substance flow analysis in the southern hemisphere: cadmium in the Australian economy. Clean Technol Environ Policy 9:175-187

48. Yano J, Hirai Y, Okamoto K, Sakai S (2013) Dynamic flow analysis of current and future end-of-life vehicles generation and lead content in automobile shredder residue. J Mater Cycles. Waste Manag 16(1):52-61

49. Chancerel P, Rotter VS (2009) Assessing the management of small waste electrical and electronic equipment through substance flow analysis - the example of gold in Germany and the USA. 2009 IEEE International Symposium on Sustainable System and Technology, ISSST'09 in Cooperation with 2009 IEEE International Symposium on Technology and Society, ISTAS.

50. Ma H-W, Matsubae K, Nakajima K, Tsai M-S, Shao K-H, Chen P-C, Lee C-H, Nagasaka T (2011) Substance Flow analysis of zinc cycle and current status of electric arc furnace dust management for zinc recovery in Taiwan. Resour Conserv Recycl $56: 134-140$

51. Brunner PH (2010) Clean cycles and safe final sinks. Waste Manag Res 28(7):575-576

52. Kral U, Kellner K, Brunner PH (2013) Sustainable resource use requires "clean cycles" and safe "final sink". Sci Total Environ 461-462:819-822

53. Brunner PH (2004) Material flow analysis and the ultimate sink. J Ind Ecol 8:4-7

54. Döberl G, Brunner PH (2004) Substances and their (final) sinks-a new indicator for monitoring sustainability. Indicators for evaluating sustainable development- the ecological dimension, Berlin, Germany

55. Kral U, Brunner PH, Chen P-C, Chen S-R (2014) Sinks as limited resources? A new indicator for evaluating anthropogenic material flows. Ecol Indic 46:596-609

56. Döberl G, Huber R, Brunner PH (2001) Final storage quality as a necessary goal for waste management. Procdedings of the ISWA world congress 2001. Stavanger, Norway

57. Brunner PH, Kral U (2014) Final sinks as key elements for building a sustainable recycling society. Sustain Environ Res 24 (6):443-448.

58. Laurent A, Bakas I, Clavrel J, Bernstad A, Niero M, Gentil E, Hauschild MZ, Christensen TH (2014) Review of LCA studies of solid waste management systems-Part I: lessons learned and perspectives. Waste Manag (Oxford) 34:573-588
59. Ekvall T, Assefa G, Björklund A, Eriksson O, Finnveden G (2007) What life-cycle assessment does and does not do in assessments of waste management. Waste Manag (Oxford) 27(8):989-996

60. Cleary $J$ (2010) The incorporation of waste prevention activities into life cycle assessments of municipal solid waste management systems: methodological issues. Int J Life Cycle Assess 15:579-589

61. Gentil E, Gallo D, Christensen TH (2011) Environmental evaluation of municipal waste prevention. Waste Manag (Oxford) 31(12):2371-2379

62. Nessi S, Rigamonti L, Grosso M (2013) Discussion on methods to include prevention activities in waste management LCA. Int J Life Cycle Assess 18:1358-1373

63. Hung M-L, Ma H-W, Yang W-F (2007) A novel sustainable decision making model for municipal solid waste management. Waste Manag (Oxford) 27(2):209-219

64. Su J-P, Chiueh P-T, Hung M-L, Ma H-W (2007) Analyzing Policy Impact Potential for Municipal Solid Waste Management Decision-Making: A Case Study of Taiwan. Resour Conserv Recycl 51 (2):418-434.

65. Su J-P, Hung M-L, Chao CW, Ma H-W (2010) Applying multicriteria decision-making to improve the waste reduction policy in Taiwan. Waste Manage Res 28:20-28

66. Chang NB, Wei YL (1999) Strategic planning of recycling drop-off stations and collection network by multiobjective programming. Environ Manage 24:247-263

67. Clearly J (2014) A life cycle assessment of residential waste management and prevention. Int J Life Cycle Assess 19:1607-1622

68. Lebersorger S, Schneider F (2011) Discussion on the methodology for determining food waste in household waste composition studies. Waste Manage (Oxford) 31(9-10):1924-1933

69. FAO (2011) Global food losses and food waste

70. Beretta C, Stoessel F, Baier U, Hellweg S (2013) Quantifying food losses and the potential for reduction in Switzerland. Waste Manage (Oxford) 33(3):764-773

71. Munesue Y, Masui T, Fushima T (2014) The effects of reducing food losses and food waste on global food insecurity natural resources and greenhouse gas emissions. Environ Econ Pol Stud 17(1):43-77

72. Møller H, Hanssen OJ, Gustavsson J, Östergren K, Stenmarck $\AA$ A, Dekhtyar P (2014) Report on review of (food) waste reporting methodology and practice. Ostfold Research, Norway

73. WRAP (2013) Household food and drink waste in the United Kingdom 2012

74. Edjabou ME, Jensen MB, Götze R, Pivnenko K, Petersen C, Scheutz C, Astrup TF (2015) Municipal solid waste composition: Sampling methodology, statistical analyses, and case study evaluation. Waste Manag (Oxford) 36:12-23

75. Richter B, Bokelmann W (2016) Approaches of the German food industry for addressing the issue of food losses. Waste Manag (Oxford) 48:423-429

76. Lebersorger S, Schneider F (2014) Food loss rates at the food retail, influencing factors and reasons as a basis for waste prevention measures. Waste Manag (Oxford) 34(11):1911-1919

77. Dias-Ferreira C, Santos T, Oliveira V (2015) Hospital food waste and environmental and economic indicators-a Portuguese case study. Waste Manag (Oxford) 46:146-154

78. Hamilton HA, Peverill MS, Müller DB, Brattebø H (2015) Assessment of food waste prevention and recycling strategies using a multilayer systems approach. Environ Sci Technol 49(24):13937-13945

79. Jepsen D, Vollmer A, Eberle U, Fels J, Schomerus T (2014) Development of tools to prevent food waste. Environmental 
Research Plan of the Federal Ministry of the Environment, Nature Conservation, Building and Nuclear Safety.

80. Schott ABS, Andersson T (2015) Food waste minimization from a life-cycle perspective. J Environ Manag 147:219-226

81. Matsuda T, Yano J, Hirai Y, Sakai S (2012) Life-cycle greenhouse gas inventory analysis of household waste management and food waste reduction activities in Kyoto, Japan. Int $\mathrm{J}$ Life Cycle Assess 17 (6):743-752

82. Martinez-Sanchez V, Tonini D, Møller F, Astrup TF (2015). Life cycle costing of food waste management: importance of indirect effects. Environ Sci Technol 50:4513-4523.

83. World Resources Institute (2013) Reducing food loss and waste. WRI, Washington, DC

84. Love DC, Fry JP, Milli MC, Neff RA (2015) Wasted seafood in the United States: Quantifying loss from production to consumption and moving toward solutions. Glob Environ Change 35:116-124.

85. Cicatiello C, Franco S, Pancino B, Blasi E (2016) The value of food waste: an exploratory study on retailing. J Retail Consum Serv 30:96-104

86. Eriksson M, Strid I, Hansson P (2015) Carbon footprint of food waste management options in the waste hierarchy-a Swedish case study. J Clean Prod 93:115-125

87. Katajajuuri J-M, Silvennoinen K, Hartikainen H, Heikkilä L, Reinikainen A (2014) Food waste in the Finnish food chain. J Clean Prod 73:322-329

88. Nessi S, Rigamonti L, Grosso M (2012) LCA of waste prevention activities: a case study for drinking water in Italy. J Environ Manag 108:73-83

89. Nessi S, Rigamonti L, Grosso M (2014) Waste prevention in liquid detergent distribution: a comparative based on life cycle assessment. Sci Total Environ 499:373-383

90. Nessi S, Rigamonti L, Grosso M (2015) Packaging waste prevention activities: a life cycle assessment of the effects on a regional waste management system. Waste Manag Res 33:833-849

91. Dolci G, Nessi S, Rigamonti L, Grosso M (2016) Life cycle assessment of waste prevention in the delivery of pasta, breakfast cereals and rice. Integr Environ Assess Manag 12(3):445-458

92. Zeng X, Li J, Liu L (2015) Solving spent lithium-ion battery problems in China: opportunities and challenges. Renew Sustain Energy Rev 52:1759-1767

93. Dolci G, Tua C, Grosso M, Rigamonti L (2016) Life cycle assessment of consumption choices: a comparison between disposable and rechargeable household batteries. Int J Life Cycle Assess 21(12):1691-1705

94. Bio Intelligence Service (2011) Comparative life-cycle assessment of nickel-cadmium (NiCd) batteries used in cordless power tools (CPTs) vs. their alternatives nickel-metal hydride $(\mathrm{NiMH})$ and Lithium-ion (Li-ion) batteries. Final report. European Commission- DG ENV 15 December 2011

95. UNEP (2005) E-waste, the hidden side of IT equipment's manufacturing and use. UNEP, DEWA/GRID-Europe, Geneve

96. Huisman J, Magalini F, Kuehr R, Maurer C, Delgado C, Artim E, Stevels ALN (2007) 2008 Review of Directive 2002/96 on Waste Electrical and Electronic Equipment (WEEE). United Nations University, Bonn

97. Chancerel P, Rotter VS (2009) Assessing the management of small waste electrical-an electronic equipment through substance flow analysis: the example of gold in Germany and the USA. 2009 IEEE International Symposium on Sustainable System and Technology, ISSST'09 in Cooperation with 2009 IEEE International Symposium on Technology and Society, ISTAS

98. The European Parliament and the Council of the European Union (2003) Directive 2002/96/EC of the European Parliament and of the Council of 27 January 2003 on waste electrical and electronic equipment (WEEE)

99. Rotter VS, Chanceral P (2012) Recycling of critical resourcesupgrade introduction. Proceedings of the Electronics Goes Green 2012+, ECG2012-Joint International Conference and Exhibition.

100. Eygen EV, Meester SD, Tran HP, Dewull J (2016) Resource savings by urban mining: The case of desktop and laptop computers in Belgium. Resour Conserv Recycl 107:53-64.

101. Chancerel P, Meskers CEM, Hagel"uken C, Rotter VS (2009) Assessment of precious metal flows during pre-processing of waste electrical and electronic equipment. J Ind Ecol 13:791-810

102. Chancerel P, Bolland T, Rotter VS (2010) Status of pre-processing of waste electrical and electronic equipment in Germany and its influence on the recovery gold. Waste Manag Res 29(3):309-317

103. Bovea MD, Ibáñez-Forés V, Pérez-Belis V, Quemades-Beltrán $P$ (2016) Potential reuse of small household waste electrical and electronic equipment: methodology and case study. Waste Manag (Oxford) 53(1):204-217

104. Kissling R, Coughlan D, Fitzpatrick C, Boeni H, Luepschen C, Andrew S, Dickenson J (2013) Success factors and barriers in re-use of electrical and electronic equipment. Resour Conserv Recycl 80:21-31.

105. Japan Automobile Manufacturers Association, Inc. (2012) World motor vehicle statistics

106. Sakai S, Yoshida H, Hiratsuka J, Vandecasteele C, Kohlmeyer R, Rotter VS, Passarini F, Santini A, Peeler M, Li J, Oh G-J, Chi NK, Bastian L, Moore S, Kajiwara N, Takigami H, Itai T, Takahashi S, Tanabe S, Tomoda K, Hirakawa T, Hirai Y, Asari M, Yano J (2014) An international comparative study of endof-life vehicle (ELV) recycling systems. J Mater Cycles Waste Manag 16:1-20

107. Xu G, Yano J, Sakai S (2015) Scenario analysis for recovery of rare earth elements from end-of-life vehicles. J Mater Cycles Waste Manag 18(3):469-482

108. Babayemi JO, Osibanjo O, Sindiku O, Weber R (2016) Inventory and substance flow analysis of polybrominated diphenyl ethers in the Nigerian transport sector-end-of-life vehicles policy and management. Environ Sci Pollut Res. doi:10.1007/ s11356-016-6574-8

109. Sakai S, Yano J, Muroi T, Watanabe N (2013) Dismantling of conventional and hybrid vehicles for end-of-life vehicle management. In: Proceedings of ISWA 2013 World Congress. Vienna, Austria

110. Cullbrand K, Magnusson O (2011) The use of potentially critical materials in passenger cars. Master's Thesis of Chalmers University of Technology, Sweden. http://studentarbeten.chalmers.se/publication/162842-the-use-of-potentially-critical-materials-in-passenger-cars. Accessed 9 July 2015

111. Alonso E, Wallington T, Sherman A, Everson M, Field F, Roth R, Kirchain R (2012) An assessment of the rare earth element content of conventional and electric vehicles. SAE Int J Mater Manuf 5(2):473-477.

112. Sander K, Kaerger W, Groke M, Bergamos M, Kohlmeyer R (2014) Separation of components and materials from end-of-life vehicles aiming at the recovery of critical metals. Proceedings of CRETE 2014 -4th International Conference on Industrial and Hazardous Waste Management, Crete, Greece

113. Widmer R, Du X, Haag O, Restrepo E, Wäger P (2015) Scarce metals in conventional passenger vehicles and end-of-life vehicle shredder output. Environ Sci Technol 49(7):4591-4599

114. Yano J, Muroi T, Sakai S (2015) Rare earth element recovery potentials from end-of-life hybrid electric vehicle components in 2010-2030. J Mater Cycles Waste Manag 18(4):655-664 
115. Du X, Restrepo E, Widmer R, Wäger P (2015) Quantifying the distribution of critical metals in conventional passenger vehicles using input-driven and output-driven approaches: a comparative study. J Mater Cycles Waste Manag 17(2):218228

116. European Commission Joint Research Centre (2011) Supporting environmentally sound decisions for construction and demolition $(\mathrm{C} \& \mathrm{D})$ Waste Management-A practical guide to Life Cycle Thinking (LCT) and Life Cycle Assessment (LCA). European Commission, Luxembourg

117. Yuan H (2013) Key indicators for assessing the effectiveness of waste management in construction projects. Ecol Indic 24:476-484

118. Saez PV, Merino MR, Gonzáleza AS-A, Amores CP (2013) Best practice measures assessment for construction and demolition waste management in building constructions. Resour Conserv Recycl 75:52-62.

119. Wu Z, Yu ATW, Shen L, Liu G (2014) Quantifying construction and demolition waste: an analytical review. Waste Manage (Oxford) 34(9):1683-1692

120. Silva RV, Brito J, Dhir RK (2014) Properties and composition of recycled aggregates from construction and demolition waste suitable for concrete production. Constr Build Mater 65:201-217

121. Deloitte SA (2014) Construction and demolition waste management in Germany.

122. Butera S, Christensen TH, Astrup TF (2015) Life cycle assessment of construction and demolition waste management. Waste Manage (Oxford) 44:196-205

123. Esa MR, Halog A, Rigamonti L (2016) Developing strategies for managing construction and demolition wastes in Malaysia based on the concept of circular economy. J Mater Cycles Waste Manag. doi:10.1007/s10163-016-0516-x

124. Wang S, Xu Z, Zhang W, Fan Z, Feng S, Liu Y (2017) Effects of aggregate reuse for overpass reconstruction-extension projects on energy conservation and greenhouse gas reduction: a case study from Shanghai City. J Clean Prod 140:1444-1453

125. Begum RA, Siwar C, Pereira JJ, Jaafar AH (2007) Implementation of waste management and minimisation in the construction industry of Malaysia. Resour Conserv Recycl 51:190-202

126. del Rio Merino M, Gracia PI, Azevedo ISW (2010) Sustainable construction: construction and demolition waste reconsidered. Waste Manag Res 28(2):118-129

127. Li J, Dong Q, Yu K, Liu L (2014) Asbestos and asbestos waste management in the Asian-Pacific region: trends, challenges and solutions. J Clean Prod 81:218-226

128. Butera S, Christensen TH, Astrup TF (2014) Composition and leaching of construction and demolition waste: inorganic elements and organic compounds. J Hazard Mat 276:302-311

129. Butera S, Trapp S, Astrup TF, Christensen TH (2015) Soil retention of hexavalent chromium released from construction and demolition waste in a road-base-application scenario. $\mathbf{J}$ Hazard Mat 298:361-367

130. Kajiwara N, Noma Y, Takigami H (2011) Brominated and organophosphate flame retardants in selected consumer products on the Japanese market in 2008. J Hazard Mat 192:1250-1259

131. Takigami H, Suzuki G, Hirai Y, Sakai S (2008) Transfer of brominated flame retardants from components into dust inside television cabinets. Chemosphere 73:161-169

132. Takigami H, Suzuki G, Hirai Y, Ishikawa Y, Sunami M, Sakai S (2009) Flame retardants in indoor dust and air of a hotel in Japan. Environ Int 35:688-693
133. Mizouchi S, Ichiba M, Takigami H, Kajiwara N, Takamuku T, Miyajima T, Kodama H, Someya T, Ueno D (2015) Exposure assessment of organophosphorus and organobromine flame retardants via indoor dust from elementary schools and domestic houses. Chemosphere 123:17-25

134. Tue NM, Takahashi S, Subramanian A, Sakai S, Tanabe S (2013) Environmental contamination and human exposure to dioxin-related compounds in e-waste recycling sites of developing countries. Environ Sci Process Impacts 15:1326-1331

135. Ma J, Cheng J, Wang W, Kunisue T, Wu M, Kannan K (2011) Elevated concentrations of polychlorinated dibenzo-p-dioxins and polychlorinated dibenzofurans and polybrominated diphenyl ethers in hair from workers at an electronic waste recycling facility in Eastern China

136. Noguchi T, Itai T, Ha NN, Tue NM, Agusa T, Hirata S, Viet PH, Takahashi S, Tanabe S (2013) Exposure assessment of lead to workers and children in the battery recycling craft village, Dong Mai, Vietnam. J Mater Cycles Waste Manag 14:46-51

137. Eguchi A, Kunisue T, Wu Q, Trang PTK., Viet PH, Kannan K, Tanabe S (2014) Occurrence of perchlorate and thiocyanate in human serum from e-waste recycling and reference sites in Vietnam: association with thyroid hormone and iodide levels. Arch Environ Contam Toxicol 67:29-41

138. Matsukami H, Tue NM, Suzuki G, Someya M, Tuyen LH, Viet PH, Takahashi S, Tanabe S, Takigami H (2015) Flame retardant emission from e-waste recycling operation in northern Vietnam: environmental occurrence of emerging organophosphorus esters used as alternatives for PBDEs. Sci Total Environ 514:492-499

139. Eguchi A, Nomiyama K, Tue NM, Trang PTK., Viet PH, Takahashi S, Tanabe S (2015) Residue profiles of organohalogen compounds in human serum from e-waste recycling sites in North Vietnam: association with thyroid hormone levels. Environ Res 137:440-449

140. Tue NM, Goto A, Takahashi S, Itai T, Asante KA, Kunisue T, Tanabe S (2016) Release of chlorinated, brominated and mixed halogenated dioxin-related compounds to soils from open burning of e-waste in Agbogbloshie (Accra, Ghana). J Hazard Mat 302:151-157

141. Bastian L, Yano J, Hirai Y, Sakai S (2013) Behavior of PCDD/ Fs during open burning of municipal solid waste in open dumping sites. J Mater Cycles Waste Manage 15(2):229-241

142. Kajiwara N, Hirata O, Takigami H, Noma Y, Tachifuji A, Matsufuji Y (2014) Leaching of brominated flame retardants from mixed wastes in lysimeters under conditions simulating landfills in developing countries. Chemosphere 116:46-53

143. Mizukawa H, Nomiyama K, Kunisue T, Watanabe MX, Subramanian A, Iwata $\mathrm{H}$, Tanabe $\mathrm{S}$ (2015) Organohalogens and hydroxylated metabolites in the blood of pigs from open waste dumping site in south India: association with hepatic cytochrome P450. Environ Res 138:255-263

144. Jones-Otazo HA, Clarke JP, Diamond ML, Archbold JA, Ferguson G, Harner T, Richardson GM, Ryan JJ, Wilford B (2005) Is House dust the missing exposure pathway for PBDEs? An analysis of the urban fate and human exposure to PBDEs. Environ Sci Technol 39(14):5121-5130

145. Asante KA, Adu-Kumi S, Nakahiro K, Takahashi S, Isobe T, Sudaryanto A, Devanathan G, Clarke E, Ansa-Asare OD, Dapaah-Siakwan S, Tanabe S (2011) Human exposure to PCBs, PBDEs and HBCDs in Ghana: Temporal variation, sources of exposure and estimation of daily intakes by infants. Environ Int 37:921-928. 